\title{
Selective quenching of fluorescence from unbound oligonucleotides by gold nanoparticles as a probe of RNA structure
}

\author{
HUIXIANG LI, RUITING LIANG, DOUGLAS H. TURNER, LEWIS J. ROTHBERG, and SHENGHUA DUAN \\ Department of Chemistry, University of Rochester, Rochester, New York 14627-0216, USA
}

\begin{abstract}
Binding of small oligonucleotides to the periphery of folded RNA can provide insight into the secondary structure of complex RNA in solution. To discriminate between bound and unbound fluorescein-labeled 2 '-O-methyl RNA probes, we use ionically coated gold nanoparticles to selectively adsorb unbound probes and quench their fluorescence. The target is the $3^{\prime}$ untranslated region of Bombyx mori R2 RNA. Fluorescence indicates that R2 sequences complementary to some of the probes are accessible for binding in the three-dimensional structure. Hybridization occurs under homogeneous conditions in the absence of the gold nanoparticles so that steric issues associated with chip-based assays are avoided. The assay is compatible with well plate formats, takes less than $5 \mathrm{~min}$, and requires only 2 pmol or less of unlabeled target RNA per probe sequence tested.
\end{abstract}

Keywords: RNA secondary structure; gold nanoparticles; fluorescence quenching; 2'-O-methyl RNA

\section{INTRODUCTION}

Elucidating the structure of RNAs is important for many reasons, including an understanding of structure-function relationships and development of therapeutics (Bloomfield et al. 1999; Gesteland et al. 2006). The complexity of RNA folding makes structural analysis difficult, time-consuming, and expensive. Although the three-dimensional structure of some RNAs can be determined by X-ray crystallography (Kim et al. 1974; Robertus et al. 1974; Cate et al. 1996; Ban et al. 2000; Wimberly et al. 2000; Schuwirth et al. 2005), it is not practical to do so for most RNAs because they are typically difficult to crystallize (Doudna 2000). The threedimensional structure of RNA can often be modeled once the secondary structure is known (Michel and Westhof 1990; Masquida and Westhof 2006), but determination of secondary structure is not trivial. Typical methods for inferring secondary structure include sequence comparison (Pace et al. 1999) and chemical or enzymatic mapping (Ziehler and Engelke 2000), where free energy minimization is often combined with either or both of these sets

Reprint requests to: Lewis J. Rothberg, Department of Chemistry, University of Rochester, Rochester, NY 14627-0216, USA; e-mail: rothberg@chem.rochester.edu; fax: (585) 276-0205.

Article published online ahead of print. Article and publication date are at http://www.rnajournal.org/cgi/doi/10.1261/rna.138807. of data (Duan et al. 2006). Binding of oligonucleotides by RNA to ascertain exposed sequences can also provide insight into RNA structure (Lewis and Doty 1970; Uhlenbeck et al. 1970; Sohail et al. 1999; Hopkins and Woodson 2005; Kierzek et al. 2006a). Conventional assays for oligonucleotide binding, such as gel electrophoresis (Pyle et al. 1994) and oligonucleotide arrays (Sohail et al. 1999; Duan et al. 2006; Kierzek et al. 2006a), are, however, time consuming and/or expensive. Moreover, chip-based assays have the disadvantage that immobilization of probes can affect their binding efficacy. Here, we report a rapid assay for hybridization of short oligonucleotide probes to RNA in solution. The assay is independent of the hybridization step, so the hybridization can be done at equilibrium under physiological or arbitrary other conditions. The assay exploits the observation that short single-stranded oligonucleotides adsorb rapidly onto gold nanoparticles (Li and Rothberg 2004a,b,c, 2005; Ray 2006) while those bound to target nucleic acids do not. The oligonucleotide probes are labeled with fluorescent tags whose emission is quenched when they adsorb onto gold nanoparticles (Dubertret et al. 2001). Therefore, the observation of fluorescence after mixing hybridization solution with gold nanoparticle suspensions indicates probe binding to the target RNA, information that can be used for structure modeling and for designing oligonucleotide therapeutics. The assay is compatible with well plate formats, takes less 
than $5 \mathrm{~min}$, and requires only 2 pmol or less of target RNA per probe sequence tested. No target labeling is required.

\section{RESULTS}

To demonstrate the assay, the $3^{\prime}$ untranslated region of Bombyx mori R2 RNA was used as the target. Its secondary structure is known from sequence comparison and chemical mapping and is shown in Figure 1A (Ruschak et al. 2004). Binding of oligonucleotides to this R2 RNA has been studied with a microarray of 2'-O-methyl 9-mers (Duan et al. 2006). Fluorescein labeled 2'-O-methyl RNA 9-mers were used as probes in the nanoparticle assay. DNA probes have been used previously in the nanoparticle assay for RNA sequences (Li and Rothberg 2005), but at a given salt concentration, $2^{\prime}$-O-methyl RNA probes bind more tightly to the target RNA than do DNA probes (Sugimoto et al. 1995; Kierzek et al. 2006b). Moreover, 2'-O-methyl probes form A-form helixes (Adamiak et al. 2001). Several probe sequences with different target binding regions were selected and are listed in Figure 1B. They are chosen as 9mers complementary to various places in the target sequence and are designated by the number of the central base in the target sequence.

The protocol for the assay is illustrated in Figure 2A and detailed in Materials and Methods. Briefly, probe and target

A

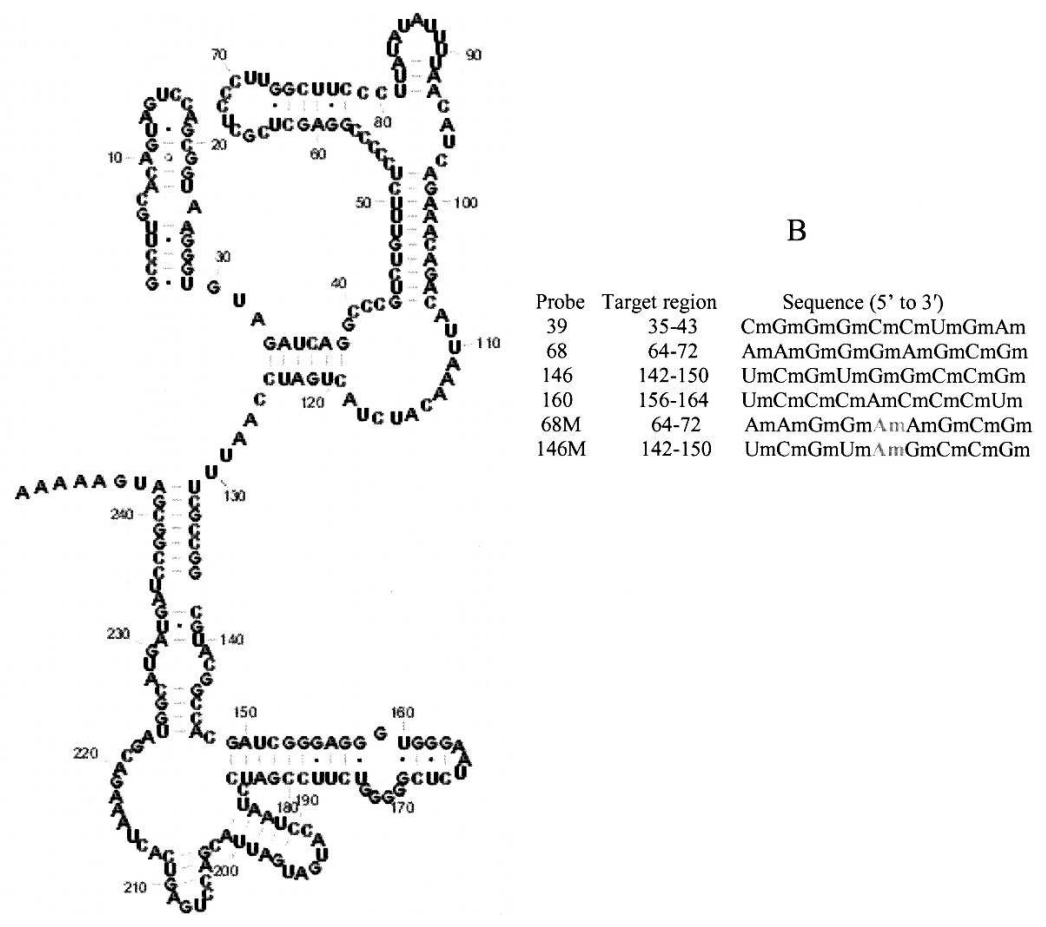

FIGURE 1. (A) Secondary structure of the $3^{\prime}$ untranslated region of B. mori R2 RNA (Ruschak et al. 2004). (B) Fluorescein-tagged 2'-O-methyl RNA probes. Probes are named by the middle nucleotide of their target region. Am, Gm, Cm, and Um represent 2'-O-methyl RNA nucleotides. Probes $68 \mathrm{M}$ and $146 \mathrm{M}$ have one-base difference denoted in bold from probes 68 and 146, respectively, and thus form single mismatches with the target. are hybridized in buffer containing $100 \mathrm{mM} \mathrm{NaCl}$ and $10 \mathrm{mM} \mathrm{MgCl}$. Then $600 \mu \mathrm{L}$ of gold nanoparticle solution is added to $2 \mu \mathrm{L}$ of the hybridization solution, and the $\mathrm{NaCl}$ concentration is restored a few seconds later by addition of $600 \mu \mathrm{L}$ of $10 \mathrm{mM}$ phosphate buffer containing $200 \mathrm{mM} \mathrm{NaCl}$ (buffer/salt solution). Photoluminescence $(\mathrm{PL})$ is then measured in a fluorometer.

Figure $2 \mathrm{~B}$ shows the emission after mixing the hybridization solutions with the gold colloid and buffer/salt solutions. There is background signal from the mixture of gold colloid and buffer/salt even in the absence of fluorescently labeled probes, as indicated by the bar labeled "no" in Figure 2B. The other black bars show the results of measurements from the mixtures of gold colloid and control solutions that contain probe but no RNA. The fact that these produce the same level of emission as the solution with no probe indicates efficient quenching of the fluorescence of free probe. Thus, observation of additional fluorescence in the presence of RNA reliably reflects binding of probe to the RNA. The gray bars represent the corresponding measurements from the mixture of gold colloid and hybridization solution containing both probe and RNA. That fluorescence is a measure of the degree of probe binding in the hybridization solution. The qualitative conclusions as to probe binding to R2 RNA are confirmed by consistency with results from gel electrophoresis (Fig. 2C) and from microarray experiments (Duan et al. 2006).

Hybridization between probe and target is done under conditions (100 $\mathrm{mM} \mathrm{NaCl}, 10 \mathrm{mM} \mathrm{MgCl}_{2}$ ) that maintain the tertiary structure of the target RNA. During the assay, this hybridization solution is mixed with relatively large volumes of colloidal gold with the effect of substantially lowering the sodium and magnesium ion concentrations. This could result in false negatives if dehybridization of the probe oligonucleotides from the target occurred rapidly and was followed by adsorption on gold and concomitant luminescence quenching. This scenario is ruled out with the control experiments presented in Figure 3. These experiments were performed with probe 146 and an RNA 9-mer (cRNA) with the sequence of target region $142-150$ to mimic the target. High levels of fluorescence are observed because the duplex does not adsorb on the gold nanoparticles and the probe fluorescence is preserved (bar 1 ). In the absence of target, the signal is essentially that of the background level due to the colloidal gold nanoparticles 

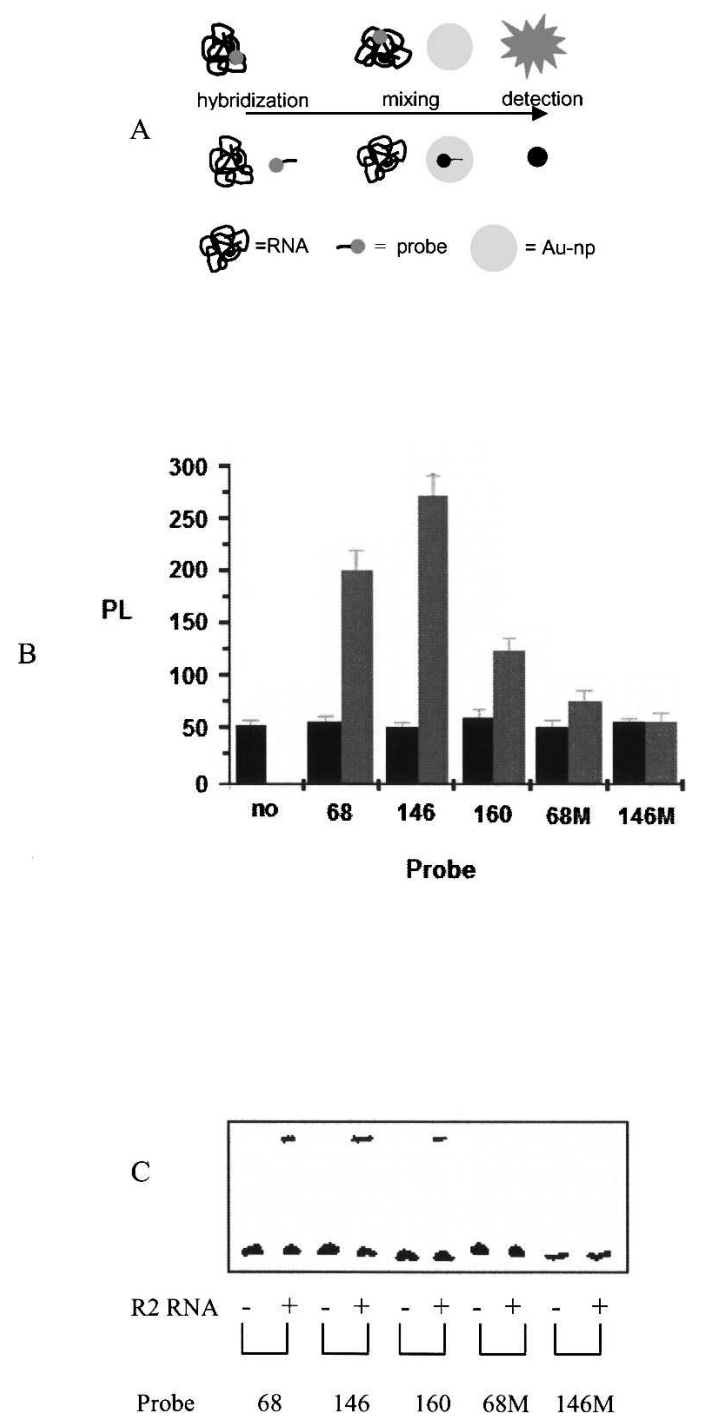

FIGURE 2. Rapid assay for RNA binding based on fluorescence quenching of tagged oligonucleotides by gold nanoparticles. $(A)$ Cartoon of assay: (top) fluorescence of probes bound to RNA target is not quenched by addition of nanoparticles; (middle) fluorescence of unbound probes is quenched by addition of nanoparticles; (bottom) key to symbols. (B) Photoluminescence (PL) for various samples. The numbers denote probe sequences specified in Figure 1. The gray bars are the fluorescence intensity at the wavelength of maximum fluorescein emission $(520 \mathrm{~nm})$ measured from hybridization solutions containing $1 \mu \mathrm{M}$ fluorescein-labeled probe and $1 \mu \mathrm{M}$ target. The black bars are analogous measurements from controls containing $1 \mu \mathrm{M}$ probes but no target. The black bar labeled "no" is a control containing gold colloid and buffer/salt solution but neither probe nor target. Fluorescence was averaged over $10 \mathrm{~s}$. Error bars are based on scatter of results from several trials. $(C)$ Photograph of native gel electrophoresis. The negative signs identify lanes containing only $10 \mu \mathrm{M}$ probe as control, while the positive signs indicate samples containing both $10 \mu \mathrm{M}$ probe and $10 \mu \mathrm{M}$ target. The bound probe/ total probe fluorescence ratio is quantified as $26 \%, 30 \%$, and $9 \%$ for probes 68,146 , and 160 , respectively. The calculated maximum ratio is $100 \%$ without considering the potential quenching of fluorescence after probe binding to target. alone (bar 2). This experiment rules out the possibility of false negatives due to substantial amounts of dehybridization under the conditions of the assay. Thus, the assay works as expected to detect the presence of simulated target using the same protocol as in Figure 2. The stability of the duplex under assay conditions is in accord with theoretical expectations based on the calculated dissociation rate for the RNA/2'-O-methyl RNA duplex. It is predicted to have a $K_{\mathrm{d}}$ of $8 \mathrm{pM}$ and a dissociation rate of $8 \times 10^{-6} \mathrm{~s}^{-1}$ at $37^{\circ} \mathrm{C}$ with $0.1 \mathrm{M} \mathrm{NaCl}$ as calculated from nearest-neighbor parameters (Kierzek et al. 2006b).

A second experiment where the complementary probe and target are mixed immediately prior to exposure to the colloid results in no fluorescence (Fig. 3, bar 3). Under these conditions, they do not have adequate time to hybridize prior to the assay, and the lack of fluorescence demonstrates that the probe adsorbs on the gold nanoparticles faster than it is able to hybridize with the target.

A third set of experiments confirms the conclusion that the state of hybridization in the trial solution prior to exposure to the colloid is for all practical purposes read accurately by the assay. Probe sequences without fluorescent tags were hybridized to the target oligonucleotide. Additional probes with fluorescent tags were added subsequently, and, whether these were incubated with the hybridization solution (Fig. 3, bar 4) or not (Fig. 3, bar 5), no fluorescence was observed, indicating that neither dehybridization of duplexes nor rehybridization of unbound complementary species occurs in the colloid.

One approach to protecting against unfolding of the RNA would be to introduce $10 \mathrm{mM} \mathrm{Mg}{ }^{2+}$ into the colloid and salt/buffer solution. Unfortunately, this has the effect of aggregating the colloid and, moreover, causes adsorption of double strands even though $100 \mathrm{mM} \mathrm{Na}{ }^{+}$does neither of these. The aggregating effect in the presence of divalent ions is well known in adsorption physics and results from conferring additional driving force for water to desorb from the nanoparticle surfaces to solvate the divalent ions (Melander and Horvath 1977), thus enhancing so-called hydrophobic interactions.

\section{DISCUSSION}

Assays of oligonucleotide binding to RNA can be useful for many purposes, including determination of RNA structure and design of oligonucleotide therapeutics (Lewis and Doty 1970; Uhlenbeck et al. 1970; Sohail et al. 1999; Duan et al. 2006; Kierzek et al. 2006a). The results in Figure 2 show that gold nanoparticles allow rapid discrimination between short fluorescently labeled oligonucleotide probes that do or do not bind a folded RNA. For example, the probes $68 \mathrm{M}$ and $146 \mathrm{M}$ that could bind with a single mismatch do not give fluorescence significantly above that observed in the absence of RNA target, whereas the perfectly matched probes 68 and 146 give fluorescence four- to fivefold above 


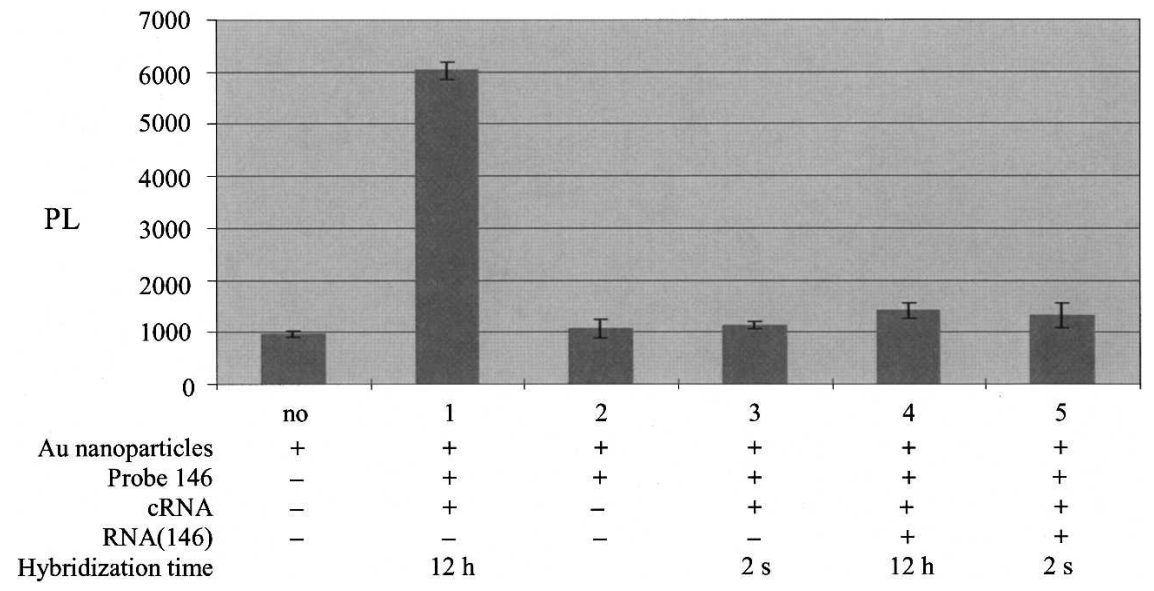

FIGURE 3. Control experiments with oligonucleotides. The conditions and methods for experiments are described in Materials and Methods. For all experiments with probes, each oligonucleotide was present at $1 \mu \mathrm{M}$ in $2 \mu \mathrm{L}$ of solution before addition of gold nanoparticles. All steps were conducted at room temperature. Probe 146 is fluorescein-labeled 2'-O-methyl oligonucleotide $5^{\prime}-\mathrm{UmCmGmUmGmGmCmCmGm}$. cRNA is the RNA oligonucleotide, $\mathrm{r}\left(5^{\prime}\right.$ CGGCCACGA), complementary to probe 146. RNA(146) has the same sequence as probe 146 but with an RNA backbone. Bar "no", probe 146 and cRNA were both absent; bar 1, probe 146 was hybridized with cRNA overnight before addition of gold nanoparticles; bar 2, probe 146 only was mixed with gold nanoparticles; bar 3, probe 146 was mixed with cRNA and gold nanoparticles were added to the mixture within $2 \mathrm{sec}$; bar 4, cRNA and RNA(146) were hybridized overnight, and probe 146 was then added to the hybridization solution and incubated overnight before gold nanoparticles were added; bar 5, cRNA and RNA(146) were hybridized overnight, probe 146 was then added, and, within $2 \mathrm{sec}$, gold nanoparticles were added. In each case, addition of gold nanoparticles was rapidly followed by addition of buffer/ salt solution.

background. As observed before with complex targets having secondary structure (Li and Rothberg 2004c, Li et al. 2007), the RNA target does not interfere with quenching of unbound probe by gold nanoparticles or allow quenching of bound probe even though the RNA has regions that are single stranded.

The binding of oligonucleotide probes can be used to test models of RNA secondary structure. Comparisons must consider many factors, however, including base pairing between probe and target, breaking of target and probe selfstructure to allow binding, and dissociation of possible probe dimers (Duan et al. 2006; Kierzek et al. 2006a). The program, OligoWalk (Duan et al. 2006), provides estimates for all these factors at $37^{\circ} \mathrm{C}$ so that a net binding free energy and apparent $K_{\mathrm{d}}$ can be estimated (Table 1). The calculations are restricted to $37^{\circ} \mathrm{C}$ because the temperature dependence of loop stabilities is uncertain. The predictions for $37^{\circ} \mathrm{C}$, however, can be reasonably compared to the experimental results at room temperature, $\sim 20^{\circ} \mathrm{C}$. The predictions by OligoWalk also use thermodynamic parameters for RNA/RNA base pairs (Xia et al. 1998), but parameters for 2'-O-methyl RNA/RNA base pairs have similar sequence dependence (Kierzek et al. 2006b). Probe 68 provides a simple example because it is complementary to a hairpin loop (Fig. 1), has no self-structure and the $1 \mu \mathrm{M}$ probe concentration is below the predicted $K_{\mathrm{d}}$ for probe dimerization (Table 1). Thus probe 68 is expected to bind tightly with an apparent $K_{\mathrm{d}}$ of $\sim 10^{-11} \mathrm{M}$. Probe 68 gives a strong fluorescence signal (Fig. $2 \mathrm{~B})$, which is consistent with the prediction based on the modeled secondary structure. On the basis of nearest-neighbor parameters (Xia et al. 1998; Mathews et al. 2004), the single mismatch in probe $68 \mathrm{M}$ is predicted to make binding less favorable by roughly $10^{5}$-fold.

Interpretations of the fluorescence enhancements due to the presence of target R2 RNA are more complicated for probes 146 and 160. Probe 160 is predicted to have an apparent $K_{\mathrm{d}}$ of $\sim 0.1 \mathrm{nM}$ (Table 1) and therefore complete binding at the $1 \mu \mathrm{M}$ concentration during hybridization. The fluorescence in the presence of target is only twice the background for probe 160 , whereas it is four times the background for probe 68 . This could reflect a twofold smaller quantum yield for bound probe 160 relative to probe 68 or, more likely, target structure beyond what is predicted for nucleotides 156-164. For example, this region might be involved in tertiary structure that hinders binding.

OligoWalk predicts probe 146 will not bind tightly to site 146 on R2 RNA (Table 1), but probe 146 gives the largest observed enhancement in fluorescence (Fig. 2B). One possible reason is that OligoWalk includes coaxial stacking terms in calculating the free energy required to break target structure but neglects them when calculating probe-target interactions. Coaxial stacking is expected to make binding of probe 146 more favorable by $4.2 \mathrm{kcal} / \mathrm{mol}$ (Walter and Turner 1994; Walter et al. 1994; Kim et al. 1996; Duan et al. 2006 ), bringing the predicted $K_{\mathrm{d}}$ to $\sim 20 \mu \mathrm{M}$ at $37^{\circ} \mathrm{C}$. The experiments were done at room temperature where the $K_{\mathrm{d}}$ should be more favorable. The results indicate that differences between predicted and measured binding must be carefully inspected and that programs for predicting binding must become more sophisticated. Experimental discrimination between probes that do or do not bind tightly is straightforward, however.

In the experiments reported here, the hybridization buffer contained $10 \mathrm{mM} \mathrm{Mg}{ }^{2+}$, which allows tertiary folding. The salt concentrations are first diluted $\sim 300$-fold, however, upon addition of the gold nanoparticles before the $\mathrm{NaCl}$ concentration is restored, and the $\mathrm{Mg}^{2+}$ concentration is diluted by another twofold upon rapid addition of the buffer/salt solution. The gold nanoparticles are added in the absence of salt to provide better discrimination between single and double strands as well as to avoid 


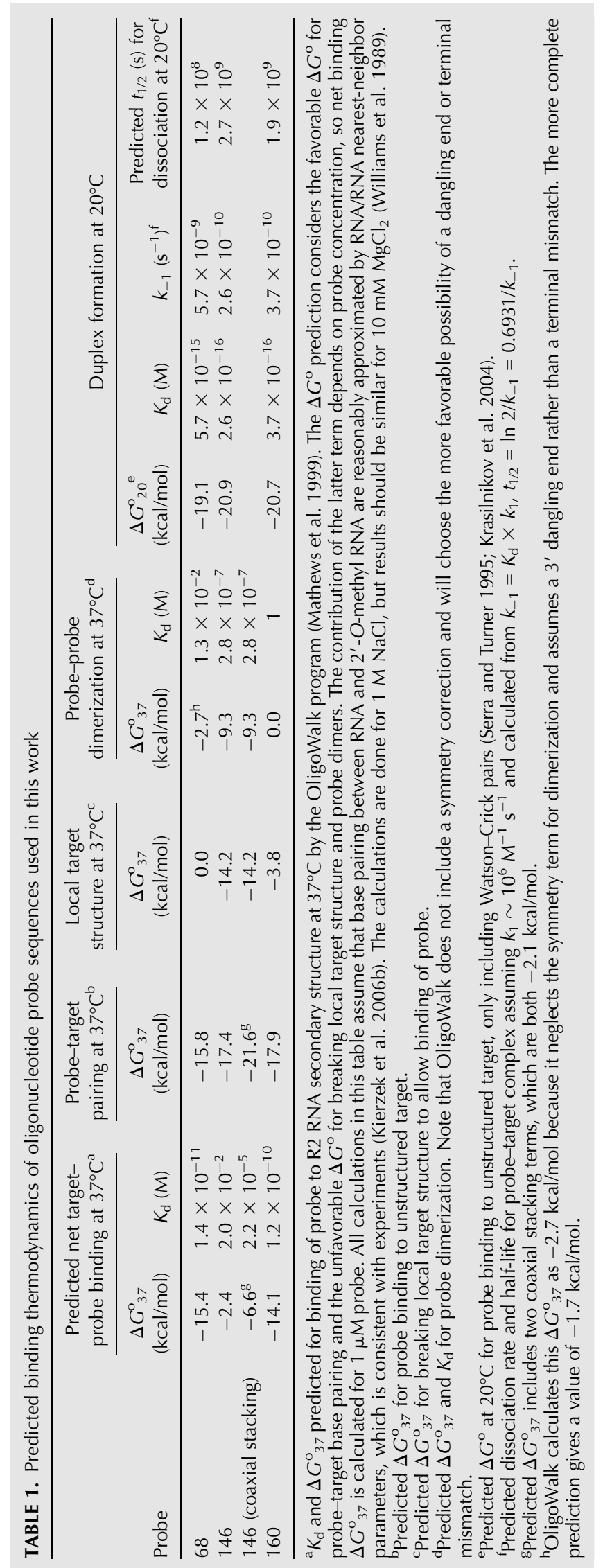


premature aggregation of the colloid. Unfolding of tertiary structure occurs with half-lives ranging from $0.01 \mathrm{~s}$ as demonstrated for tRNA (Maglott et al. 1998) and RNase P (Fang et al. 2000, 2002) to at least between 3 and $35 \mathrm{~s}$, as demonstrated for the Tetrahymena thermophila self-splicing intron (Bevilacqua et al. 1992; Zhuang et al. 2000). Thus, it is possible for the RNA to be partially unfolded during the course of the assay. This is not likely to have a large effect on the observed binding, however. Hybridization rates to unstructured targets are typically on the order of $10^{6} \mathrm{M}^{-1} \mathrm{~s}^{-1}$, so the half-life for binding is $\sim 300 \mathrm{~s}$ when each nucleic acid strand concentration is $1 / 300=0.003 \mu \mathrm{M}$. The assay is complete in less than $30 \mathrm{~s}$, and the fluorescence of all probes tested alone was quenched during this time (Fig. 2B), so it is unlikely that probes have time to bind any unfolded RNA. This assertion is confirmed by the control experiments of Figure 3 that allow us to rule out hybridization to a 9-mer complementary to the probe.

It is also unlikely that bound probes will dissociate while the salt concentration is low. The shortest half-life predicted for dissociation of probe from a completely complementary target site at $20^{\circ} \mathrm{C}$ is roughly 4 yr at $1 \mathrm{M} \mathrm{NaCl}$ (Table 1) and is expected to be similar at the $0.1 \mathrm{M} \mathrm{NaCl}$ present during the fluorescence measurement (Porschke et al. 1973; Long et al. 2007). The calculation ignores potential increases in dissociation rate due to strand invasion, which is poorly understood. Nevertheless, probes initially bound to target in the hybridization buffer should remain bound during the roughly $30 \mathrm{~s}$ required for the nanoparticle assay. The results of the control experiments in Figure 3 are consistent with these predictions. Thus, the experiments reported here interrogate the secondary structure of R2 RNA present at $10 \mathrm{mM} \mathrm{Mg}{ }^{2+}$. Clearly, instrumentation specially designed for these measurements would allow lower concentrations and a shorter time lag between hybridization and fluorescence measurement, thus further assuring interrogation of structures as they are under hybridization conditions.

The nanoparticle assay is simple, reliable, and free of issues that arise from binding to immobilized probes in a microarray format. It can be easily converted into an automated high-throughput parallel assay with 96- or 384-well plates. Multiplexing is also possible by including different sequence probes with different dye labels in a mixture. For example, the dyes rhodamine, fluorescein, and Cy5 have all been used with DNA in the nanoparticle assay (Li and Rothberg 2004a,c, 2005; Li et al. 2007). It is therefore well suited to providing insight into the structure of an RNA and into design of oligonucleotide therapeutics by rapidly determining which probes bind to the RNA. The method would be straightforward to miniaturize. Total volumes of $\sim 1 \mathrm{~mL}$ were used because the commercial fluorometer accommodated cuvettes with $1 \mathrm{~cm}$ path length. Much of the sample was not involved in the measurement, however. Simple improvements in optics, such as using laser excitation and smaller sample volumes, should improve sensitivity by several orders of magnitude so that only subfemtomole quantities of target are required for each probe sequence to be assayed. The method should also be applicable to studying the unfolding of RNA (Hopkins and Woodson 2005).

\section{MATERIALS AND METHODS}

\section{Synthesis of gold nanoparticles}

The colloidal solution of gold nanoparticles was synthesized as described previously (Grabar et al. 1995). Briefly, $250 \mathrm{~mL}$ of $1 \mathrm{mM}$ $\mathrm{HAuCl}_{4}$ (Alfa Aesar, Ward Hill, MA) was heated to its boiling point while stirring. Then $25 \mathrm{~mL}$ of $38.8 \mathrm{mM}$ sodium citrate (Alfa Aesar) was quickly added to the boiling solution, which was boiled and stirred for another $15 \mathrm{~min}$. The solution was cooled to room temperature where it can be stored indefinitely for use.

\section{Synthesis of oligonucleotides}

The 2'-O-methyl RNA probes with fluorescein attached to the $5^{\prime}$ end with a C6 linker were synthesized on an Applied Biosystems 392 DNA/RNA synthesizer using the phosphoramidite method (Caruthers et al. 1992). Phosphoramidites and CPG support were purchased from Glen Research. Cleavage of the oligonucleotides from universal II CPG was done by incubating with $2 \mathrm{M}$ ammonia in methanol (Sigma Aldrich) at room temperature for $30 \mathrm{~min}$. The solution was dried down, and 1:1 (v/v) concentrated ammonium anhydride/ammonia in methylamine (AMA) (Sigma Aldrich) was added; the sealed vial was incubated at $65^{\circ} \mathrm{C}$ for $10 \mathrm{~min}$ or room temperature for $2 \mathrm{~h}$. The solution was dried down and residue was purified on a large preparative Baker Si500F TLC silica gel plate $(20 \mathrm{~cm} \times 20 \mathrm{~cm}, 500 \mu \mathrm{m}$ thick $)$ with a 55:35:10 (v/v/v) 1-propanol/ammonia/water running solution. The product was identified by UV shadowing and scraped from the plate. Oligonucleotides were extracted from the silica with distilled water. The water solution was dried down, and the purified oligonucleotides were dissolved in $5 \mathrm{mM}$ ammonium bicarbonate at $\mathrm{pH}$ 7.0. The solution was loaded onto a Waters Sep-Pak C18 chromatography column to remove excess salts. Purities of all oligonucleotides were checked with a Hewlett-Packard 1100 HPLC Chemstation and were $>95 \%$. Molecular weights were determined by ESI-MS with a Hewlett-Packard 1100 LCMS Chemstation. RNA oligonucleotide 5'-CGGCCACGA and its complement 5'-UCGUGGCCG were purchased from Integrated DNA Technologies, Inc., and purified by TLC as described above.

\section{RNA target purification}

B. mori R2 3' UTR RNA was prepared following the protocol of Ruschak et al. (2004). The B. mori R2 3' UTR sequence was cloned into pUC19 plasmid and transfected into E. coli cells. The Qiagen Midi plasmid preparation kit protocol was used for plasmid extraction. The plasmids were linearized by XmnI (Promega). The plasmid DNA was transcribed with T7 RNA polymerase (Ambion MEGAScript), and the RNA was purified on an $8 \%$ polyacrylamide denaturing gel. RNA was excised from the gel and electroeluted. The solution was desalted and concentrated on a filter with a $10 \mathrm{~K}$ cutoff membrane (Millipore). 


\section{Hybridization}

A $10 \mu \mathrm{L}$ RNA solution containing 1.0 or $10 \mu \mathrm{M}$ B. mori R2 3' UTR RNA in hybridization buffer (40 mM HEPES, $40 \mathrm{mM}$ sodium HEPES, $100 \mathrm{mM} \mathrm{NaCl}, 10 \mathrm{mM} \mathrm{MgCl}_{2}, \mathrm{pH} 7.5$ ) was incubated at $45^{\circ} \mathrm{C}$ for $30 \mathrm{~min}$ and then cooled slowly to room temperature. Control solutions for R2 experiments contain all the ingredients except R2 RNA. A $1 \mu \mathrm{L}$ solution of 10 or $100 \mu \mathrm{M}$ fluorescent probe in water was dried down in an Eppendorf tube, and then the $10 \mu \mathrm{L}$ sample solution was added to give a probe concentration of 1 or $10 \mu \mathrm{M}$ for use in nanoparticle and gel experiments, respectively. The mixed solution was incubated at $4^{\circ} \mathrm{C}$ overnight. The incubation conditions were chosen to ensure equilibrium, while minimizing the risk of hydrolysis, and to allow comparisons to microarray experiments on the same system (Duan et al. 2006).

\section{Fluorescence detection}

Time traces of fluorescence were recorded at room temperature on a fluorometer (Fluorolog 3, Jobin Yvon) with excitation and emission at 480 and $520 \mathrm{~nm}$, respectively. Both excitation and emission slits were set for $4 \mathrm{~nm}$ band-pass. Fluorescence was recorded from mixtures of $2.0 \mu \mathrm{L}$ of hybridization solution containing $1.0 \mu \mathrm{M}$ probe and $1.0 \mu \mathrm{M}$ target after mixing first with $600 \mu \mathrm{L}$ gold colloid solution (synthesized as described above and as pink as the original gold nanoparticle solution) and a few seconds later with $600 \mu \mathrm{L}$ of $10 \mathrm{mM}$ phosphate buffer containing $200 \mathrm{mM} \mathrm{NaCl}$ at room temperature. The fluorescence was averaged over $10 \mathrm{~s}$.

\section{Native gel electrophoresis}

Samples containing $10 \mu \mathrm{M}$ R2 RNA and $10 \mu \mathrm{M}$ probe were run on a $4 \%$ polyacrylamide native gel at $4^{\circ} \mathrm{C}$. The running buffer was $50 \mathrm{mM}$ Tris acetate ( $\mathrm{pH}$ 7.8). After it was run, the gel was directly scanned on a Molecular Dynamics PhosphorImager by choosing the green laser option.

Received May 9, 2007; accepted July 27, 2007.

\section{REFERENCES}

Adamiak, D.A., Rypniewski, W.R., Milechi, J., and Adamiak, R.W. 2001. The $1.19 \AA \mathrm{X}$-ray structure of $2^{\prime}-\mathrm{O}-\mathrm{Me}(\mathrm{CGCGCG})_{2}$ duplex shows dehydrated RNA with 2-methyl-2,4-pentanediol in the minor groove. Nucleic Acids Res. 29: 4144-4153. doi: 10.1093/ nar/29.20.4144

Ban, N., Nissen, P., Hansen, J., Moore, P.B., and Steitz, T.A. 2000. The complete atomic structure of the large ribosomal subunit at $2.4 \AA$ resolution. Science 289: 905-920.

Bevilacqua, P.C., Kierzek, R., Johnson, K.A., and Turner, D.H. 1992. Dynamics of ribozyme binding of substrate revealed by fluorescence-detected stopped-flow methods. Science 258: 1355-1358.

Bloomfield, V.A., Crothers, D.M., and Tinoco Jr., I. 1999. Nucleic acids: Structures, properties, and functions. University Science Books, Sausalito, CA.

Caruthers, M.H., Beaton, G., Wu, J.V., and Wiesler, W. 1992. Chemical synthesis of deoxyoligonucleotides and deoxyoligonucleotide analogs. Methods Enzymol. 211: 3-20.

Cate, J.H., Gooding, A.R., Podell, E., Zhou, K., Golden, B.L., Kundrot, C.E., Cech, T.R., and Doudna, J.A. 1996. Crystal structure of a group I ribozyme domain: Principles of RNA packing. Science 273: 1678-1685.
Doudna, J.A. 2000. Structural genomics of RNA. Nat. Struct. Biol. 7: 954-956.

Duan, S., Mathews, D.H., and Turner, D.H. 2006. Interpreting oligonucleotide microarray data to determine RNA secondary structure: Application to the $3^{\prime}$ end of Bombyx mori R2 RNA. Biochemistry 45: 9819-9832.

Dubertret, B., Calame, M., and Libchaber, A. 2001. Single-mismatch detection using gold-quenched fluorescent oligonucleotides. Nat. Biotechnol. 19: 365-370.

Fang, X., Littrell, K., Yang, X.J., Henderson, S.J., Siefert, S., Thiyagarajan, P., Pan, T., and Sosnick, T.R. 2000. $\mathrm{Mg}^{2+}$-dependent compaction and folding of yeast tRNAPhe and the catalytic domain of the B. subtilis RNase P RNA determined by small-angle $\mathrm{X}$-ray scattering. Biochemistry 39: 11107-11113.

Fang, X.-W., Thiyagarajan, P., Sosnick, T.R., and Pan, T. 2002. The rate-limiting step in the folding of a large ribozyme without kinetic traps. Proc. Natl. Acad. Sci. 99: 8518-8523.

Gesteland, R.F., Cech, T.R., and Atkins, J.F. 2006. The RNA world, 3rd ed. Cold Spring Harbor Press, Cold Spring Harbor, NY.

Grabar, K.C., Freeman, R.G., Hommer, M.B., and Natan, M.J. 1995. Preparation and characterization of Au colloid. Anal. Chem. 67: 735-743.

Hopkins, J.F. and Woodson, S.A. 2005. Molecular beacons as probes of RNA unfolding under native conditions. Nucleic Acids Res. 33: 5763-5770. doi: 10.1093/nar/gki877.

Kierzek, E., Kierzek, R., Turner, D.H., and Catrina, I.E. 2006 a. Facilitating RNA structure prediction with microarrays. Biochemistry 45: 581-593.

Kierzek, E., Mathews, D.H., Ciesielska, A., Turner, D.H., and Kierzek, R. 2006b. Nearest neighbor parameters for Watson-Crick complementary heteroduplexes formed between 2'-O-methyl RNA and RNA oligonucleotides. Nucleic Acids Res. 34: 36093614. doi: 10.1093/nar/gkl232.

Kim, J., Walter, A.E., and Turner, D.H. 1996. Thermodynamics of coaxially stacked helixes with GA and CC mismatches. Biochemistry 35: 13753-13761.

Kim, S.H., Suddath, F.L., Quigley, G.J., McPherson, A., Sussman, J.L., Wang, A.H., Seeman, N.C., and Rich, A. 1974. Three-dimensional tertiary structure of yeast phenylalanine transfer RNA. Science 185: 435-440.

Krasilnikov, A.S., Xiao, Y., Pan, T., and Mondragon, A. 2004. Basis for structural diversity in homologous RNAs. Science 306: 104-107.

Lewis, J.B. and Doty, P. 1970. Derivation of the secondary structure of 5S RNA from its binding of complementary oligonucleotides. Nature 225: 510-512.

Li, H. and Rothberg, L.J. 2004a. Colorimetric detection of DNA sequences based on electrostatic interactions with unmodified gold nanoparticles. Proc. Natl. Acad. Sci. 101: 14036-14039.

Li, H. and Rothberg, L.J. 2004b. Label-free colorimetric detection of specific sequences in genomic DNA amplified by the polymerase chain reaction. J. Am. Chem. Soc. 126: 10958-10961.

Li, H. and Rothberg, L.J. 2004c. Label-free DNA sequence detection using selective fluorescence quenching of tagged oligonucleotide probes by gold nanoparticles. Anal. Chem. 76: 5414-5417.

Li, H. and Rothberg, L.J. 2005. Rapid detection of specific sequences in RNA using differential adsorption of single-stranded oligonucleotides on gold nanoparticles. Anal. Chem. 77: 6229-6233.

Li, H., Ascroft, L., Brooks, A.I., Russell, R., Wildt, S., and Rothberg, L.J. 2007. Selective quenching of unhybridized fluorescent probes by gold nanoparticles for rapid SNP genotyping using conventional PCR. In Proceedings of the 2nd IEEE Intl. Workshop on Advances in Sensors and Interfaces, pp. 26-30. IEEE, New York.

Long, D., Lee, R., Williams, P., Chan, C.Y., Ambros, V., and Ding, Y. 2007. Potent effect of target structure on microRNA function. Nat. Struct. Mol. Biol. 14: 287-294.

Maglott, E.J., Deo, S.S., Przykorska, A., and Glick, G.D. 1998. Conformational transitions of an unmodified tRNA: Implications for RNA folding. Biochemistry 37: 16349-16359. 
Masquida, B. and Westhof, E. 2006. A modular and hierarchical approach for all-atom RNA modeling. In The RNA world, 3rd ed. (eds. R.F. Gesteland, T.R. Cech, and J.F. Atkins), pp. 659-681. Cold Spring Harbor Laboratory Press, Cold Spring Harbor, NY.

Mathews, D.H., Burkard, M.E., Freier, S.M., Wyatt, J.R., and Turner, D.H. 1999. Predicting oligonucleotide affinity to nucleic acid targets. RNA 5: 1458-1469.

Mathews, D.H., Disney, M.D., Childs, J.L., Schroeder, S.J., Zuker, M., and Turner, D.H. 2004. Incorporating chemical modification constraints into a dynamic programming algorithm for prediction of RNA secondary structure. Proc. Natl. Acad. Sci. 101: 72877292.

Melander, W. and Horvath, C. 1977. Salt effects on hydrophobic interactions in precipitation and chromatography of proteins: An interpretation of the lyotropic series. Arch. Biochem. Biophys. 183: 200-215.

Michel, F. and Westhof, E. 1990. Modelling of the three-dimensional architecture of group I catalytic introns based on comparative sequence analysis. J. Mol. Biol. 216: 585-610.

Pace, N.R., Thomas, B.C., and Woese, C.R. 1999. Probing RNA structure, function, and history by comparative analysis. In The RNA World, 2nd ed. (eds. R.F. Gesteland, T.R. Cech, and J.F. Atkins), pp. 113-141. Cold Spring Harbor Laboratory Press, Cold Spring Harbor, NY.

Porschke, D., Uhlenbeck, O.C., and Martin, F.H. 1973. Thermodynamics and kinetics of helix-coil transition of oligomers containing GC base pairs. Biopolymers 12: 1313-1335.

Pyle, A.M., Moran, S., Strobel, S.A., Chapman, T., Turner, D.H., and Cech, T.R. 1994. Replacement of the conserved G.U with a G-C pair at the cleavage site of the Tetrahymena ribozyme decreases binding, reactivity, and fidelity. Biochemistry 33: 13856-13863.

Ray, P.C. 2006. Diagnostics of single base-mismatch DNA hybridization on gold nanoparticles by using the hyper-Rayleigh scattering technique. Angew. Chem. Int. Ed. 45: 2162.

Robertus, J.D., Ladner, J.E., Finch, J.T., Rhodes, D., Brown, R.S., Clark, B.F., and Klug, A. 1974. Structure of yeast phenylalanine tRNA at $3 \AA$ resolution. Nature 250: $546-551$.

Ruschak, A., Mathews, D., Bibillo, A., Spinelli, S., Childs, J., Eickbush, T., and Turner, D. 2004. Secondary structure models of the 3' untranslated regions of diverse R2 RNAs. RNA 10: 978987.
Schuwirth, B.S., Borovinskaya, M.A., Hau, C.W., Zhang, W., VilaSanjurjo, A., Holton, J.M., and Cate, J.H. 2005. Structures of the bacterial ribosome at $3.5 \AA$ resolution. Science 310: $827-834$.

Serra, M.J. and Turner, D.H. 1995. Predicting thermodynamic properties of RNA. Methods Enzymol. 259: 242-261.

Sohail, M., Akhtar, S., and Southern, E.M. 1999. The folding of large RNAs studied by hybridization to arrays of complementary oligonucleotides. RNA 5: 646-655.

Sugimoto, N., Nakano, S., Katoh, M., Matsumura, A., Nakamuta, H., Ohmichi, T., Yoneyama, M., and Sasaki, M. 1995. Thermodynamic parameters to predict stability of RNA/DNA hybrid duplexes. Biochemistry 34: 11211-11216.

Uhlenbeck, O.C., Baller, J., and Doty, P. 1970. Complementary oligonucleotide binding to the anticodon loop of fMet-transfer RNA. Nature 225: 508-510.

Walter, A.E. and Turner, D.H. 1994. Sequence dependence of stability for coaxial stacking of RNA helixes with Watson-Crick base paired interfaces. Biochemistry 33: 12715-12719.

Walter, A.E., Turner, D.H., Kim, J., Lyttle, M.H., Muller, P., Mathews, D.H., and Zuker, M. 1994. Coaxial stacking of helixes enhances binding of oligoribonucleotides and improves predictions of RNA folding. Proc. Natl. Acad. Sci. 91: 9218-9222.

Williams, A.P., Longfellow, C.E., Freier, S.M., Kierzek, R., and Turner, D.H. 1989. Laser temperature-jump, spectroscopic, and thermodynamic study of salt effects on duplex formation by dGCATGC. Biochemistry 28: 4283-4291.

Wimberly, B.T., Brodersen, D.E., Clemons Jr., W.M., MorganWarren, R.J., Carter, A.P., Vonrhein, C., Hartsch, T., and Ramakrishnan, V. 2000. Structure of the 30 S ribosomal subunit. Nature 407: 327-339.

Xia, T., SantaLucia Jr., J., Burkard, M.E., Kierzek, R., Schroeder, S.J., Jiao, X., Cox, C., and Turner, D.H. 1998. Thermodynamic parameters for an expanded nearest-neighbor model for formation of RNA duplexes with Watson-Crick base pairs. Biochemistry 37: 14719-14735.

Zhuang, X., Bartley, L.E., Babcock, H.P., Russell, R., Ha, T., Herschlag, D., and Chu, S. 2000. A single-molecule study of RNA catalysis and folding. Science 288: 2048-2051.

Ziehler, W.A. and Engelke, D.R. 2000. Probing RNA structure with chemical reagents and enzymes. In Current protocols in nucleic acid chemistry, Vol. 2, pp. 6.1.1-6.1.21. Wiley-VCH, Weinheim, Germany. 

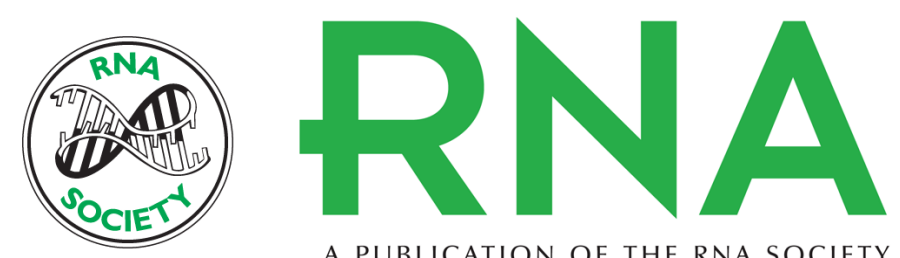

A PUBLICATION OF THE RNA SOCIETY

\section{Selective quenching of fluorescence from unbound oligonucleotides by gold nanoparticles as a probe of RNA structure}

Huixiang Li, Ruiting Liang, Douglas $\mathrm{H}$. Turner, et al.

RNA 2007 13: 2034-2041 originally published online September 25, 2007

Access the most recent version at doi:10.1261/rna.138807

References This article cites 45 articles, 14 of which can be accessed free at:

http://rnajournal.cshlp.org/content/13/11/2034.full.html\#ref-list-1

License

Email Alerting Receive free email alerts when new articles cite this article - sign up in the box at the Service top right corner of the article or click here.

To subscribe to $R N A$ go to:

http://rnajournal.cshlp.org/subscriptions 